The International Journal of Indian Psychology: Volume: 01 | Issue: 04 | ISSN 2348-5396

\title{
Mental Health of Working and Non Working Women in Ahmadabad
}

\author{
Kiranben Vaghela*
}

Present researches have been done to know the effect of Working and Non Working Women's mental health. For this Total number of sample was 60 in which 30 working women from the age group of 20 to 40 years; And 30 non working women were taken the same age group. For the data collection MHI (Mental Health Inventory) by Dr. A. K Shriwastav was used for data analysis and concluded result ' $t$ ' test was used. For this dimension implies that in positive sense that there is significant difference between working and non working women. The result indicate that working women a lot differ on mental health score as compared to non working women, working women have shown better mental health in compared to non working women .

\section{Introduction:}

Psychological diseases like stress, anxiety. Depression etc are burning problem of this area in every society and in every country. Science and technological revolution in different sphere of industrial production has been start in the last portion of this previous century. Some people know it as nuclear era, electronic era space era or information and technology era. However in reality the time is era of "Hurry and Worry". The effect of hurry and worry uncertainty, restlessness, tension and stress can feel here and there.

In this modern times people lose their physic strength because of that even losing their mental health too and become more aware for become patient of psychosomatic disorder. Because of that all are become more aware for mental health as compare to physical health. Here we all have a question, "what is mental health?" Different psychologists are trying to defined mental health by different way.

According to Sullivan, a healthy person is one who has syntaxes relationship with others and who reacts to people as they really are, not as symbol of past relationship. Thus, emphasis is on interpersonal relationship. Alder defined a healthy personality as one which experiences a sense of identification against infantile feeling of inferiority and helplessness.

Korchin (1976) believes that the concept of psychological health must focus on the ideal state, i.e. emphasis on the "positive well being" rather than on disease, statistical or conformity criteria.

*PhD Scholar, Department of Psychology, Sardar Patel University, Vallabh Vidhya Nagar Anand 


\section{The International Journal of Indian Psychology: Volume: 01 | Issue: 04 | ISSN 2348-5396}

Godoy, Fernander, Garcia and Gonzaler (1983), argued that health must defined as a state of physical, social and psychological well rather than simply as an absence of illness or infinity. They also stressed the importance of development of human potentials illness considered a reflection of individual response to stress and change in the social culture, economics and psychological environment.

There are many various factors effect on mental health, one of them is women. Present research is done to know that effect of working and non working women on mental health.

\section{Problem of study}

The problem of the present study is as under:

"A Comparative study of mental health among working and non working women"

\section{Objectives of the study:}

The main objectives of present study are as under:

1. To study of the mental health among working and non working women.

2. To study and compare the various dimension of mental health of working and non working women in khokhara area.

\section{Hypothesis}

The main hypothesis of present study is as under:

1. There is no significant difference between working and non working women in various dimension of mental health.

2. There is no significant difference between working and non working women in positive self evaluation.

3. There is no significant difference between working and non working women in perception of reality.

4. There is no significant difference between working and non working women in integration of personality.

5. There is no significant difference between working and non working women in autonomy.

6. There is no significant difference between working and non working women in oriented attitudes.

7. There is no significant difference between working and non working women in environmental mastery. 
The International Journal of Indian Psychology: Volume: 01 | Issue: 04 | ISSN 2348-5396

\section{Variables}

The variables of present study are having given in following.

\section{In dependent variable:}

Working and non working women in khokhara area.

\section{Dependent variable:}

Various dimension of mental health are measured by M.H.I

\section{Sample:}

The main aim of the present research is "A comparative study of mental health of working and non working women". For this total no of sample were 60 in which 30 working women from the age group of 20 to 40 years. And 30 non working women were taken from the same age group.

\section{Tool:}

In the present research for the data collection Mental Health Inventory (M.H.I) by Dr. jagdish and Dr. A.K Shrivastava was used.

Mental Health Inventory (M.H.I) measure various dimension of mental health. They are Positive Self Evaluation (PSE), Perception of Reality (PR), Integration of Personality(IR), Autonomy(AUTNY), Group Oriented Attitude (GOA), Environmental Mastery(EM) and Overall in M.H.I. it has four alternative responses. They are 'always' 'often' 'rarely' and 'never' different sentences measure different dimension of mental health. Total score of every sentence measure overall mental health reliability of the test is 0.54 and validity of the test is 0.79 .

\section{Procedure:}

After establishing report mental health inventory were administered individuals to every subject. All the instruction were strictly following which are been given the manual of inventory. The responses of inventory have scored as per scoring keys; which has given in the manual of inventory. The data was categories and arranged in respective table according to the stoical technique appraised.

\section{Statically Analysis}

The main aim of the present research is to study and compare to mental health between working and non working women. Scoring was done as per scoring key of the inventory to examine significantly difference between working and non working women. For data analysis ' $t$ ' test was used.
(C) 2014 www.ijip.in
July-September 2014
55 | P a g e 
The International Journal of Indian Psychology: Volume: 01 | Issue: 04 | ISSN 2348-5396

\section{Results}

Table: 1

$\mathrm{N}=60$

Show in Mean, $\mathrm{SD}$, and ' $\mathrm{t}$ ' ratio of various group of age on score of various dimensions of mental health

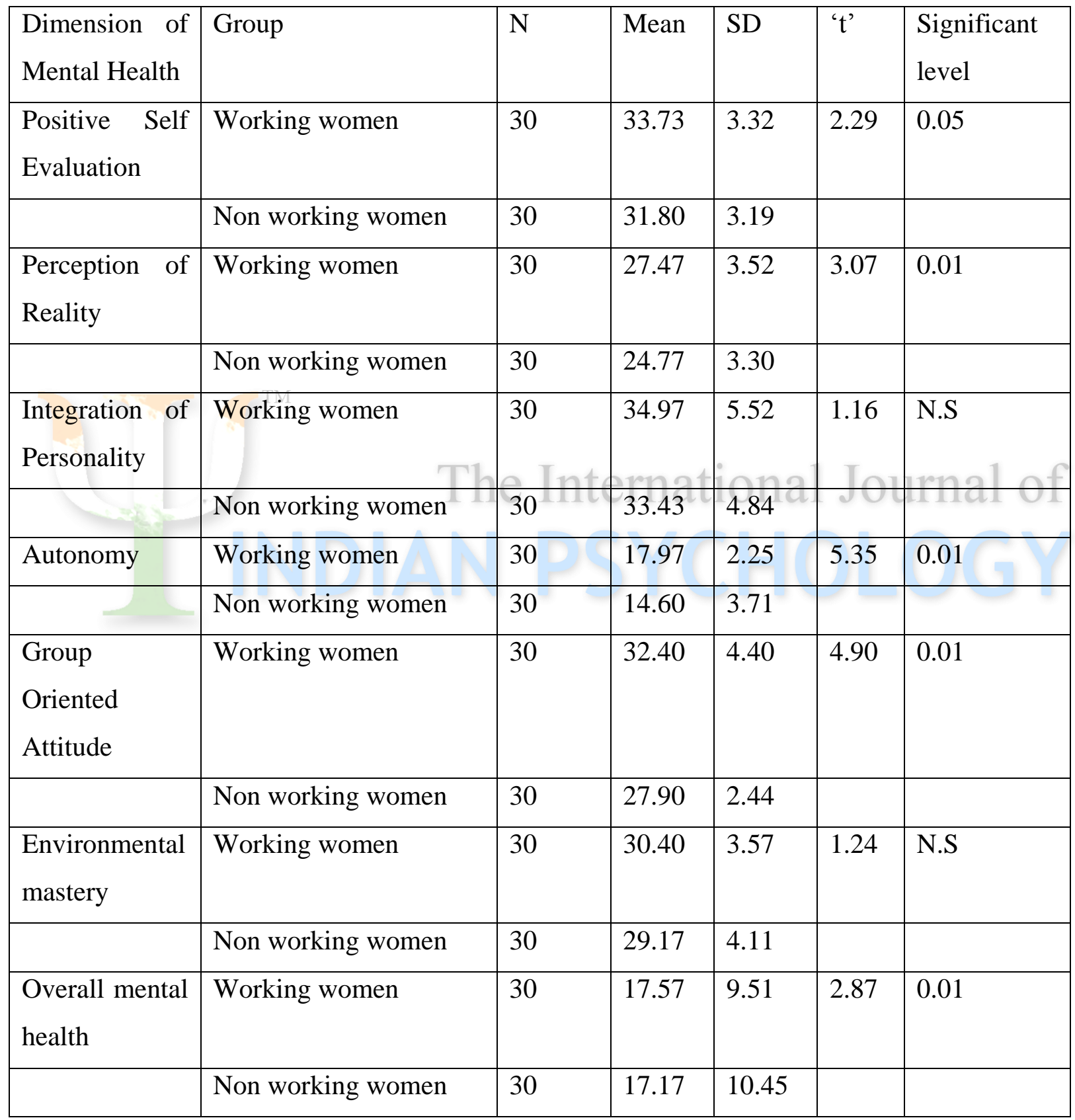




\section{The International Journal of Indian Psychology: Volume: 01 | Issue: 04 | ISSN 2348-5396}

\section{Discussion:}

In result table an attempt is to find out the different between working and non working women in various dimension of mental health score with ' $t$ ' test.

' $t$ ' value of working and non working women of positive self evaluation score is 2.29 , which is significant act 0.05 level. It means working women are significant differ on Positive Self Evaluation score as compare to non working women. Working women have shown better Positive Self Evaluation by getting high mean score $\mathrm{M}=33.73$ then non working women mean $\mathrm{M}=31.80$.

' $t$ ' value of working and non working women of perception of reality is 3.07 which is significant at 0.01 level. It means working women are significant differ on Perception of Reality score as compare to non working women. Working women have shown better Perception of Reality by getting high mean score $M=27.47$ then non working women mean $M=24.77$

' $t$ ' value of working and non working women of Integration of Personality is 1.16 which is not significant. Working women have shown better Integration of Personality by getting high mean score $\mathrm{M}=34.97$ then non working women $\mathrm{M}=33.43$

' $t$ ' value of working and non working women of Autonomy is 5.35 which is significant at 0.01 level. It means working women are significant differ on Autonomy score as compare to non working women. Working women have shown better Autonomy by getting high mean score $\mathrm{M}=17.97$ then non working women $\mathrm{M}=14.60$

' $t$ ' value of working and non working women of Group Oriented Attitudes is significant at 0.01 level. It means working are working women significant differ on oriented attitudes score as compare to non working women. Working women have shown better Oriented Attitudes by getting high mean score $\mathrm{M}=32.40$ then non working women $\mathrm{M}=27.90$

' $t$ ' value of working and non working women of Environmental Mastery is 1.24 which is not significant. Working women have shown better Environment Mastery by getting high mean score $\mathrm{M}=30.40$ then non working women $\mathrm{M}=29.17$

' $t$ ' value of working and non working women of Overall Mental Health is 2.87 which is significant at 0.01 level. It means working women are significantly differ on overall mental health score as compare to non working women have shown better overall mental health score as compare to non working women. Working women have shown better overall mental health by getting high mean score $\mathrm{M}=17.57$ then non working women $\mathrm{M}=17.17$.
(C) 2014 www.ijip.in
July-September 2014
$57 \mid \mathrm{P}$ a g e 
The International Journal of Indian Psychology: Volume: 01 | Issue: 04 | ISSN 2348-5396

\section{Reference}

1. Grohol, J., (2008). What is Good Mental Health?. Psych Central. Retrieved on March 13,2014 , from

2. Jump up to: ${ }^{a} \underline{b}$ About.com (2006, July 25). What is Mental Health?. Retrieved June 1, 2007, fromAbout.com

3. Online Etymology Dictionary. (2001). "Psychology"

4. Ryff, C. D., Keyes CLM. The structure of psychological well-being revisited. J Pers Soc Psychol1995;69:719-727.

5. Thomson Healthcare (2007). Ranking America's Mental Health: An Analysis of Depression Across the United States.

6. World Health Organization. Strengthening Mental Health Promotion. Geneva, World Health Organization (Fact sheet no. 220), 2001.

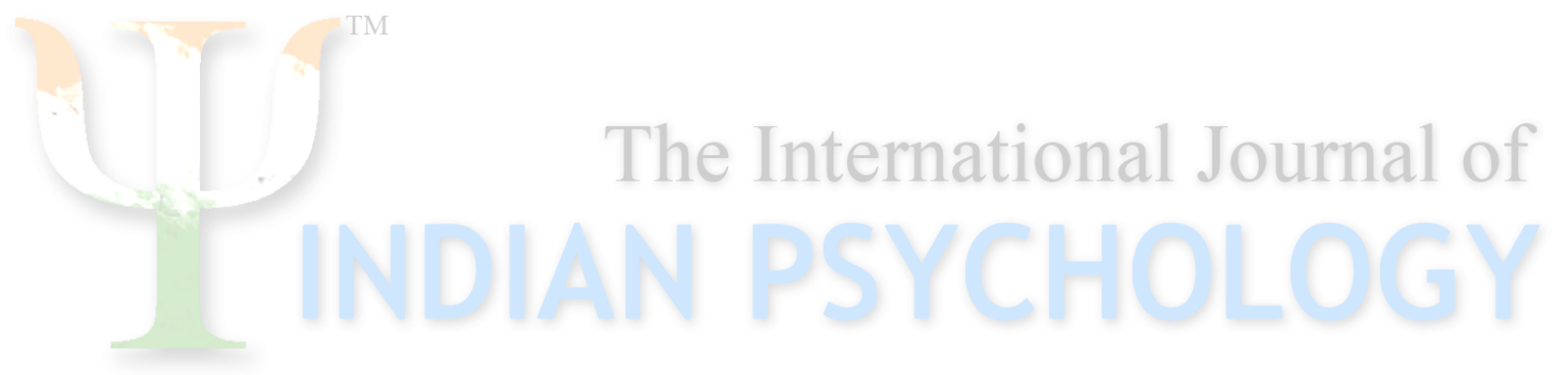

